\title{
TINGGALAN PERANG DUNIA II DAN KONSEPTUALISASI MUSEUM DI MOROTAI
}

\section{The Remains of The World War II and the Conceptualization of Museum in Morotai}

\author{
Syahruddin Mansyur \\ Balai Arkeologi Ambon \\ Jl. Namalatu-Latuhalat Ambon 97118 \\ hitam_putih07@yahoo.com
}

Naskah diterima: 03-01-2013; direvisi: 19-04-2013; disetujui: 10-05-2013

\begin{abstract}
Morotai Island is one of the locations which left many traces of World War II in Indonesia. This suggests that Morotai Island has a strategic geographical position for the two military forces involved at the time. In this context, the legacy of World War II in Morotai has important historical value to be preserved, one of them through the establishment of a museum. This study aimed to develop appropriate thematic concept for presentation of the museum. Literature study and field observations conducted to obtain data related to the historical and archaeological remains exist in the study area. The results of this study, obtained information about the actual condition of archaeological remains exist in Morotai, as well as the formulation of the concept of thematic presentation of the exhibition. Thus, early studies of this thematic concepts can provide the storyline, so as to give weight to the information of the existing archaeological remains in the Morotai.
\end{abstract}

Keywords: Morotai, Museum, World War II, Exhibition.

\begin{abstract}
Abstrak
Pulau Morotai merupakan salah satu lokasi yang banyak meninggalkan jejak Perang Dunia II di Indonesia. Hal ini menunjukkan bahwa Pulau Morotai memiliki posisi geografis yang strategis bagi dua kekuatan militer yang terlibat saat itu. Dalam konteks inilah, peninggalan Perang Dunia II yang ada di Morotai memiliki nilai sejarah yang penting untuk dilestarikan, salah satunya melalui pendirian sebuah museum. Penelitian ini bertujuan untuk menyusun konsep tematik yang tepat bagi penyajian museum. Studi pustaka dan observasi lapangan dilakukan untuk memperoleh data terkait dengan sejarah dan tinggalan arkeologi yang ada di lokasi penelitian. Hasil kajian ini, diperoleh informasi tentang kondisi aktual tinggalan arkeologi yang ada di Morotai, serta rumusan tentang konsep tematik penyajian pameran. Dengan demikian, studi awal konsep tematik ini dapat memberikan alur cerita atau storyline, sehingga mampu memberikan bobot informasi tinggalan arkeologi yang ada di Morotai.
\end{abstract}

Kata Kunci: Morotai, Museum, Perang Dunia II, Pameran.

\section{PENDAHULUAN}

Dalam konteks Perang Dunia II, Pulau Morotai dikenal sebagai pangkalan militer Pasukan Sekutu dalam upaya penyerangan terhadap kekuatan militer Jepang di Philipina. Invasi kekuatan militer Jepang dalam Perang Dunia II saat itu, menguasai hampir seluruh kawasan Asia-Pasifik, sehingga pada 15 September 1944, Pasukan Sekutu di bawah pimpinan Jenderal Douglas Mac. Arthur berhasil melakukan pendaratan dan merebut Pulau Morotai dari militer Jepang. Pasukan Sekutu kemudian berhasil menjadikan Morotai sebagai pangkalan utama yang 
berlanjut dengan keberhasilan mereka menguasai Philipina. Keberhasilan in sekaligus menjadi bagian awal keberhasilan Pasukan Sekutu memenangkan Perang Dunia II. Hal ini menunjukkan posisi geostrategis Pulau Morotai sebagai wilayah yang berbatasan langsung dengan Philipina Dengan demikian, dapat dikatakan bahw Morotai sebagai pangkalan militer sekutu menjadi titik penting Pasukan Sekutu dalam memenangi Perang Dunia II. Fakta historis inilah yang menjadikan tinggalan Perang Dunia II yang ada di Pulau Morotai memiliki nilai sejarah yang tinggi.

Berdasarkan latar sejarah di atas, tinggalan Perang Dunia II yang masih ada di Pulau Morotai memiliki nilai sejarah yang tinggi. Oleh karena itu, berbagai pihak pun berupaya melestarikan berbagai tinggala arkeologi yang ada di Pulau Morotai. Sala satunya adalah mendirikan sebuah museum yang dapat memberikan informasi tentang periode Perang Dunia II di Pulau Morotai. Langkah ini mulai ditempuh oleh sekelompok masyarakat yang peduli akan tinggalan arkeologi di Pulau Morotai dengan mendirikan sebuah museum mini yang menampilkan berbagai bentuk tinggalan Perang Dunia II Sebagai sebuah embrio museum, koleksi museum mini cukup lengkap mulai dar peralatan perang hingga peralatan sehari-har tentara sekutu pada saat itu ditampilkan d museum ini. Melalui dedikasi yang tinggi, seorang pemuda bernama Mukhlis Eso berhasil memberikan keyakinan kepada rekan-rekannya untuk peduli pada tinggalan Perang Dunia II di Pulau Morotai. Mukhlis Eso kemudian membentuk sebuah kelompok yang mereka namakan Kelompok Masyaraka Pecinta Pusaka Perang Dunia II (Perang Pasifik) Sementara itu, pihak pemerinta daerah melalui Dinas Kebudayaan dan Pariwisata juga menyadari potensi tinggalan Perang Dunia II di Pulau Morotai dan memberikan dukungan kepada masyaraka dalam upaya pelestariannya. Namun, karen kendala birokrasi, dukungan konkrit belum dirasakan oleh kelompok masyarakat yang dipimpin oleh Mukhlis Eso.

Dengan demikian, dapat disimpulkan bahwa tinggalan arkeologi yang ada $d i$ Pulau Morotai merupakan sumberdaya yang memiliki nilai penting dan harus dilestarikan. Oleh karena itu, dibutuhkan kerjasama antar stakeholder dalam upaya pelestarian sumberdaya arkeologi. Pihakpihak yang berkepentingan diantaranya adalah masyarakat yang tergabung dalam Kelompok Masyarakat Pecinta Pusaka Perang Dunia II dan Pemerintah Kabupaten Pulau Morotai. Dalam konteks inilah, terjadi konflik kepentingan antara masyaraka dan Pemerintah Daerah dalam pengelolaan sumberdaya arkeologi yang ada di Pulau Morotai.

Wacana tentang pendirian museum Perang Dunia II di Pulau Morotai semaki mengemuka setelah penyelenggaraan Sai Indonesia di Pulau Morotai pada bulan September 2012. Dalam hal ini, wacana pendirian museum telah diambil alih oleh Pemerintah Pusat dan Pemerintah Daerah dalam rangka menunjang program nasiona dengan menjadikan Pulau Morotai sebagai kawasan ekonomi terpadu, termasuk dalam hal ini adalah meningkatkan kepariwisata di Pulau Morotai. Terkait dengan wacana tersebut, tulisan ini dimaksudkan sebaga sumbangan pemikiran terkait dengan konsep tematik pameran (storyline atau alur cerita) yang diharapkan mampu memberi gambaran tentang periode Perang Dunia II di Pulau Morotai. Tidak hanya itu, konsep tematik pameran juga difokuskan pada kondisi peninggalan Perang Dunia II yang saat in masih tersisa di Pulau Morotai.

Sebagaimana uraian sebelumnya, tampak jelas bahwa tinggalan arkeologi yan ada di Pulau Morotai memiliki nilai penting terkait dengan pe Perang Dunia II. Menyadari hal tersebut, berbagai pihak pun berupaya mengelola dan melestarikannya. Masyarakat sebagai salah satu stakeholder dalam pengelolaan sumberdaya arkeolog di Pulau Morotai telah berperan sert dengan mendirikan sebuah museum mini yang menampilkan berbagai tinggalan arkeologi yang merupakan sisa Perang Dunia II. Museum yang saat ini dikelola oleh masyarakat Morotai dapat dikatakan sebagai embrio museum, karena apa yang dimaksud dengan museum adalah sebuah bangunan semi permanen yang menampilkan berbagai tinggalan arkeologi terkait dengan periode Perang Dunia II.

Adapun permasalahan yang berusaha dijawab dalam penelitian ini adalah bagaimana konsep tematik yang tepat bagi penyajian pameran museum Perang Dunia II di Morotai. Oleh karena itu, untuk menjawab permasalahan ini maka langkah awal adalah melakukan indentifikasi tinggalan arkeologi yang berkaitan dengan Perang Dunia II yang ada di Pulau Morotai serta menelusuri informasi kesejarahan tentang periode Perang Dunia II di Pulau Morotai, baik masa pendudukan Militer Jepang maupun masa pendudukan Pasukan Sekutu. Dengan demikian, kajian ini sebagai upaya pengembangan museum dalam kaitan memberi bobot informasi tinggalan arkeologi terkait periode Perang Dunia II di Morotai.

\section{METODE}

Pada dasarnya, penelitian ini merupakan penelitian arkeologi dan penelitian museologi. Tahapan awal untuk mengidentifikasi tinggalan arkeologi digunakan metode observasi yaitu melakukan pengamatan terhadap objek-objek arkeologi yang ada di lokasi penelitian. Tahapan selanjutnya, penelitian ini menggunakan selanjutnya, penelitian ini menggunakan
salah satu tahapan kerja museologi yaitu fase konseptual. Tahapan ini merupakan tahapan awal dalam sebuah proyek pameran museum yang bertujuan untuk merumuskan sebuah konsep tematik pameran (Dean, 2002: 9). Oleh karena itu, penelitian ini menggunakan metode yang dapat memberikan pemahaman metode yang dapat memberikan pemahaman tentang fenomena yang diteliti melalui
gambaran holistik dan memperbanyak gambaran holistik dan mingga digunakan pendekatan kualitatif (Moleong, 2008:31; Mansyur, 2010a:13). Gambaran holistik dan pemahaman mendalam dimaksud di antaranya tentang gambaran umum periode Perang Dunia II di Morotai, kondisi aktual tinggalan Perang Dunia II di Morotai, dan berbagai ha terkait dengan berlangsungnya Perang Dunia II di Morotai. Selanjutnya, penelitian in menggunakan tahapan penelitian yaitu tahap pengumpulan data, tahap pengolahan data, dan tahap penarikan kesimpulan.

Pengumpulan data dilakukan dengan dua cara yakni melalui studi pustaka dan observasi langsung ke lapangan. Jenis dat yang dikumpulkan dalam studi literatur adalah semua laporan atau hasil penelitian maupun arsip yang berkaitan dengan keberadaan latar sejarah Perang Dunia II di Morotai. Sementara itu, observasi lapangan berupaya menjaring data artefaktual dan data lingkungan yang dapat menjawab permasalahan penelitian. Observasi lapangan juga meliputi deskripsi verbal, dan piktorial. Metode wawancara yang digunakan yaitu wawancara terbuka untuk mengumpulkan data sejarah, keadaan sosial, ekonomi dan budaya masyarakat setempat. Secara umum, pengumpulan data dalan tulisan ini bersumber dari hasil penelitian arkeologi yang dilakukan pada tahun $2011 \mathrm{di}$ Morotai (Tim Penelitian, 2011: 8-26).

Data yang sudah dikumpulkan, melalui studi literatur dan observasi di lapangan kemudian diidentifikasi untuk menjelaskan periode Perang Dunia II di Morotai. Dalam tahap pengolahan data dilakukan deskrips terhadap hasil-hasil penelitian, berupa data arkeologi, naskah dan tradisi masyarakat yang diperoleh berdasarkan informasi lisan dan studi pustaka. Analisis dalam penelitian in berdasarkan data yang diperoleh di lapangan adalah kegiatan menjalin dan mensintesakan data untuk memperoleh kesimpulan. Pada tahap akhir dilakukan penarikan kesimpulan untuk memperoleh konsep tematik pameran.

\section{HASIL DAN PEMBAHASAN \\ . Latar Sejara}

Berdasarkan fokus permasalahan penelitian tentang studi awal pendirian 
museum Perang Dunia II, maka uraian latar sejarah akan difokuskan pada periode antara tahun 1942 hingga tahun 1944. Periode pertama Perang Dunia II di Morotai diawal dengan keberhasilan militer Jepang merebu wilayah ini dari tangan Belanda pada mas itu. Periode selanjutnya adalah periode pendaratan pasukan sekutu yang menjadikan pulau ini sebagai pangkalan militer dalam upaya serangan ke Philipina dan Jepang.

Di kawasan Asia-Pasifik, Perang Dunia II dikenal dengan Theater of Pacifik, diawali dengan serangan dadakan Jepang ke pangkalan militer Amerika Serikat di Pasifik (Pearl Harbour) pada 7 Desember 1941. Meski di kawasan Asia (daratan), Jepang telah melakukan invasi ke daratan China sejak 1931, namun serangan ke Pear Harbour dianggap menjadi pemicu utama keterliban kedua negara dalam Perang Dunia II. Dengan demikian, Jepang telah membuka dua front pertempuran yaitu Asia Daratan (China hingga Burma) dan Kawasan Pasifik (Wikipedia, 2011)

Setelah berhasil dalam serangan ke Pearl Harbour, kawasan Asia Tenggar yaitu Filipina, Malaya (Malaysia), Hindia Belanda (Indonesia), serta Australia dan New Zealand terbuka bagi serangan Jepang. Dalam berbagai sumber disebutkan, keterlibatan Jepang dalam kancah Perang Dunia II tidak lepas dari embargo minyak oleh Amerika Serikat dan Inggris. Faktor lain adalah upaya untuk mempersatukan negara-negara Asia d bawah kekuasaan Jepang serta membebaskan kawasan Asia dari imprealisme Barat, sehingga bagi Jepang perang ini disebut " $D a$ Toa no Senso" (Perang Asia Timur Raya). Dengan alasan inilah, Jepang kemudian melakukan serangan susulan ke kawasan Pasifik Barat Daya (Hindia Belanda), setelah terlebih dahulu menguasai Filipina serta memaksa Amerika Serikat meninggalkan negara tersebut. Tujuan utama front baru in adalah menguasai ladang minyak yang ada di Kalimantan (Tarakan dan Balikpapan) Demikian halnya, ladang minyak yang ad di Pulau Timor yang saat itu berada di bawah kekuasaan bangsa Portugis (Ojong, 2006: 7; Mansyur, 2011: 53).

Gelombang serangan Eastern Octopus yang berpusat di Davao Filipina, diawal serangan ke Tarakan pada tanggal 10 Januar 1942. Berturut-turut kemudian, serangan terhadap Manado 11 Januari, Balikpapan dan Kendari 24 Januari, Ambon 30 Januari, Makassar 9 Februari, Banjarmasin 16 Febas. 910 Februari, Bali 19 Februari, dan Nusa Tenggar Timur 20 Februari (Ojong, 2006: 6; Mansyur 2011: 53). Setelah berhasil menguasai seluruh wilayah Hindia Belanda, Jepang kemudian menetapkan tiga wilayah pemerintahan militer, yaitu wilayah Sumatera diperintah oleh Tentara Ke-25 Angkatan Darat Jepang yang bermarkas di Bukittinggi, Jawa-Bal oleh Tentara Ke-16 Angkatan Darat Jepang yang bermarkas di Batavia (Jakarta), serta Kalimantan, Sulawesi, Nusa Tenggara, Maluku dan Papua (wilayah timur) oleh Armada Ke-3 Angkatan Laut Jepang yang bermarkas di Makassar (Marsono, 2005: 65; Mansyur, 2011: 53). Gelombang serangan terhadap wilayah Hindia Belanda, selain dimaksudkan untuk menguasai sumbersumber minyak, sekaligus merupakan upaya militer Jepang untuk melumpuhkan kekuata Hindia Belanda yang saat itu berpusat di Jawa Aspek strategis lain, bahwa secara geografis (khususnya wilayah timur) penguasaan atas wilayah ini dimaksudkan untuk mendekatkan pangkalan militer Jepang ke wilayah Australia yang saat itu merupakan salah satu bagian dari kekuatan Sekutu.

a. Periode Pendudukan Jepang di Morotai Periode ini sekaligus merupakan periode awal Perang Dunia II di Morotai, dimana pada tahun 1942, militer Jepang dengan kekuatan satu batalyon berhasil mendarat di Morotai melalui Sangowo dan membuat tiga pos penjagaan yaitu di Sangowo, Totodokoe, dan Doruba. Pendaratan pasukan Jepang di Morotai disertai dengan mobilisasi peralatan perang yang terdir atas berbagai jenis kendaraan tempur dan berbagai jenis senjata. Selain itu, Jepang membangun prasarana berupa jaringan jalan, jaringan listrik, dan landasan pesawat serta lubang-lubang pertahanan. Selain di Morotai, pusat-pusat pertahanan Jepang di wilayah ini pusat-pusat pertahanan Jepang di wilayah ini diantaranya: Ternate, Kao, Wasilei, Tobelo, Galela, dan Bacan. Di setiap lokasi tersebut, selain membangun lubang-lubang pertahanan, Jepang juga membuat lapangan terbang diantaranya: Wasilei, Meti (Tobelo), Galela, dan Bacan. Di Morotai sendiri, Jepang membuat dua lapangan terbang yaitu di lokasi yang saat ini dikenal dengan SP 2 (daerah transmigrasi) dan di MTQ di Morotai Selatan.

Pembangunan sarana-sarana pertahanan oleh Jepang, melibatkan penduduk setempat yang diperkerjakan secara paksa atau sering disebut Romusha. Berbagai kisah mengiringi pelaksanaan kerja paksa diantaranya, kelompok-kelompok kerja paksa yang terdiri atas sembilan orang seringkali dikurangi anggotanya apabila kelompok tersebut dinilai bermalas-malasan untuk menyelesaikan suatu pekerjaan oleh tentara Jepang. Dalam setiap pekerjaan itu pula, para pekerja diberi upah sebesar 5 Cent dan itupun harus dipotong pajak sebesar 4 Cent.

b. Periode Pendaratan Pasukan Sekutu

Menghadapi laju militer Jepang di wilayah Asia-Pasifik, pada tanggal 15 Januari 1942, negara-negara Eropa, Amerika dan Australia yang memiliki kepentingan atas wilayah ini membentuk aliansi yang disebut dengan ABDA (Amerika, Inggris, Belanda dan Australia). Amerika yang berkepentingan atas wilayah Pasifik (termasuk Philipina), Belanda dan Australia yang berkepentingan atas wilayah Hindia Belanda, dan Inggris yang berkepentingan atas wilayah Asia Daratan (termasuk Singapura). Aliansi keempat negara yang disebut juga dengan negara-negara sekutu kemudian menyusun strategi untuk menghalau militer Jepang dari kawasan ini.

Pendaratan pasukan sekutu di Morotai merupakan bagian dari rencana besar sekutu untuk melakukan serangan balik terhadap kekuatan militer Jepang di wilayah Pasifik Strategi yang dipilih oleh Amerika dalam rencana tersebut adalah taktik lompat katak mengingat wilayah ini merupakan kepulauan. Taktik ini dimaksudkan untuk melemahkan posisi militer Jepang dengan tujuan akhi yaitu melakukan serangan khusus di wilayah Kepulauan Jepang yang dapat mendesak penyerahan Jepang terhadap pihak sekutu. Oleh karena itu, tujuan pertama dari serangan ini adalah merebut Philipina yang merupakan pangkalan militer Amerika yang telah direbut oleh Jepang. Dengan demikian, serangan dititikberatkan di wilayah Pasifik yang kemudian diarahkan ke Philipina lewa Papua dan Morotai yang berbatasan langsung dengan Philipina.

Pendaratan pasukan sekutu di Morotai elah direncanakan sejak awal September 1944, menyusul keberhasilan pasukan sekutu menduduki Biak. Serangan terhadap Morotai sebenarnya telah diperkirakan oleh Jepang mengingat posisi strategis pulau ini yang berdekatan dengan Philipina, namun Jepang tidak menduga bahwa serangan ke Morotai merupakan serangan besar-besaran. Akhirnya, pada tanggal 15 September 1944 sekutu melakukan pendaratan di Daroeba sekaligus penyerangan terhadap tentara Jepang di Pilowo, Gotalalamo, Totodoku, Sabatai dan Toea. Pada saat pendaratan pasukan sekutu, tentara Jepang hanya berkekuatan 500 personil di bawah pimpinan Mayor Takenabu Kawashima. Kekuatan militer Jepang pada saat itu lebih di fokuskan di pulau Halmahera, yaitu Kao, dan Malifut. Sehingga pasukan sekutu di bawah pimpinan Jenderal Doughlas Mc. Arthur lebih memilih Morotai sebagai sasaran pendaratan untuk kemudian dijadikan pangkalan militer dalam rangka serangan ke Philipina. Jenderal Doughlas Mc. Arthtur sendiri memiliki ambis pribadi untuk membuktikan ucapannya, "I shall return", ketika terdesak oleh serangan Jepang di Philipina dan harus melarikan dir ke Australia. Kekuatan pasukan sekutu dalam serangan ini adalah 40.105 personil dari US Army dan 16.915 yang merupakan gabungan 
dari US Army Air Forces (USAAF) dan Roya Australian Air Force (RAAF) (Wikipedia, 2012).

Sebelum serangan ke Morotai, pasukan sekutu telah melakukan berbagai persiapan termasuk latihan pendaratan yang dilakukan di Aitape dan Wakde. Persiapan lain adalah melakukan pengintaian terhadap kekuatan Jepang di Morotai dan sekitarnya. Sekutu memperkirakan bahwa di daerah-daerah yang berada dalam jangkauan kekuatan udar ke Morotai, Jepang memiliki 582 pesawa berbagai jenis. Oleh karena itu, sekutu melancarkan serangan yang dikhususkan untuk melumpuhkan kekuatan udara Jepang yang ada di Mindanao, Halmahera, Sulawesi, Seram, Ambon, dan Buru, selama period Agustus 1943 hingga Oktober 1945. Dalam hal ini, Ambon dilihat sebagai "sayap kiri" kekuatan militer Jepang di wilayah Pasifik, sementara itu Kepulauan Pasifik Tengah (Palaus, Bismarck dan Marshall) adalah kekuatan "sayap kanan" (Australian Wa Memory, 2011; Mansyur, 2011: 57). Dengan demikian, serangan ini sekaligus bertujuan untuk memutus rangkaian kekuatan milite Jepang yang ada di wilayah pasifik barat daya (Indonesia). Terputusnya rangkaian kekuatan tersebut, membuat Amerika lebih leluasa memusatkan kekuatan militernya untuk merebut Filiphina dengan menjadikan Morotai (Maluku Utara) sebagai pangkalan militer (Mansyur, 2011: 58).

Untuk menjaga efek kejutan, Sekutu tidak melakukan serangan udara ke Morota sebelum pendaratan tanggal 15 September Hal yang dilakukan oleh sekutu adala mempelajari detail pulau Morotai melalui pengintaian foto udara termasuk titik pendaratan yang aman di pulau ini. Pada tanggal 12 September 1944, pasukan sekutu berangkat dari Teluk Maffin dan tiba pada pag hari tanggal 15 di Morotai tanpa terdeteks oleh pasukan Jepang. Pertempuran di Morotai dimulai pada pagi hari jam 6:30, yang diawal dengan serangan bom oleh kapal-kapal perang sekutu di sepanjang pantai. Kemudian, pada pukul 08:30, gelombang pertama menjelang esok harinya pasukan sekutu telah bergerak ke pedalaman dan mengamankan area sejauh 1.800 meter. Kurangnya personil yang ditempatkan di Morotai menyebabkan pasukan Jepang terdesak dan melarikan diri ke daerah pedalaman. Beberapa bantuan melalui serangan udara yang dilakukan oleh divisi ke-7 angkatan udara Jepang yang bermarkas di Seram dan Sulawesi tidak memberi efek berarti terhadap laju pasukan sekutu di Morotai. Meski kalah dalam jumlah personil, pasukan Jepang terus melakukan perlawanan dan menyerang markas pasukan sekutu secara ketika sekutu menyatakan Morotai telah aman, jumlah korban di pihak sekutu yaitu 30 personil tewas, 85 terluka, dan satu dinyatakan hilang, sementara korban di pihak Jepang sebanyak 300 personil tewas, dan 13 lainnya ditangkap. Meskitelah dinyatakan aman oleh sekutu, namun pasukan Jepang yang tersisa masih bertahan dan bermarkas di daerah perbukitan. Operasi terakhir yang dilakukan oleh sekutu akhirnya berhasil menemukan markas tersebut pada tanggal 1 Januari 1945 dan pertempuran berakhir pada tangoal 14 Dengan demikian, jumlah korban selama operasi sekutu di Morotai bertambah menjadi 46 tewas dan 104 luka-luka di pihak sekutu, sementara di pihak Jepang sebanyak 870 tewas dan 10 ditawan. Jumlah korban tewas di pihak Jepang bertambah menginga bantuan pasukan Jepang yang dikirim dari luar Morotai (Historynet, 2012).

Selama perang berlangsung, tujuan sekutu menjadikan Morotai sebagai pangkalan militer tetap berjalan. Berbagai sarana dan prasarana dibangun oleh pasukan sekutu untuk mendukung serangan mereka ke wilayah Philipina dan Jepang, diantaranya, lapangan terbang yang memiliki tujuh landasan yang dibuat dengan mengeraskan batu karang dengan minyak hitam yang dikenal dengan Pitu Strip, ditempat lain sekutu juga membuat satu landasan pacu darurat yang terbuat dari pelat besi. Selain itu, sekutu membuat dermaga yang terbuat dari pelat besi dan instalasi penyimpanan bahan bakar yang mampu menampung 129.000 barel bahan bakar, serta menjadikan pulau Sum-Sum sebagai pusat komando serangan ke Philipina. Fasilitas lain adalah sebuah rumah sakit berkapasitas 1.900 tempat tidur. Seluruh fasilitas ini selesai pada awal oktober, sehingga serangan ke Philipina terlaksana pada akhir Oktober 1944. Dalam serangan ke Philipina, pasukan sekutu dilengkapi dengan 3.000 pesawat tempur dan 63 batalyon tempur (Smith, 2012).

\section{Identifikasi Tinggalan Arkeologi}

Secara administratif, lokasi penelitian berada di Kota Daruba, Kabupaten Pulau Morotai. Kabupaten Pulau Morotai memiliki luas wilayah yaitu $2.314,9 \mathrm{~km}^{2}$ dengan luas daratan 495, $69 \mathrm{~km}^{2}$, sebagian besar daerah okupasi merupakan daerah pesisir dimana terdapat 57 desa/kelurahan yang merupakan desa pantai. Sementara itu, kondisi demografi berdasarkan data tahun 2010, Kabupaten Pulau Morotai

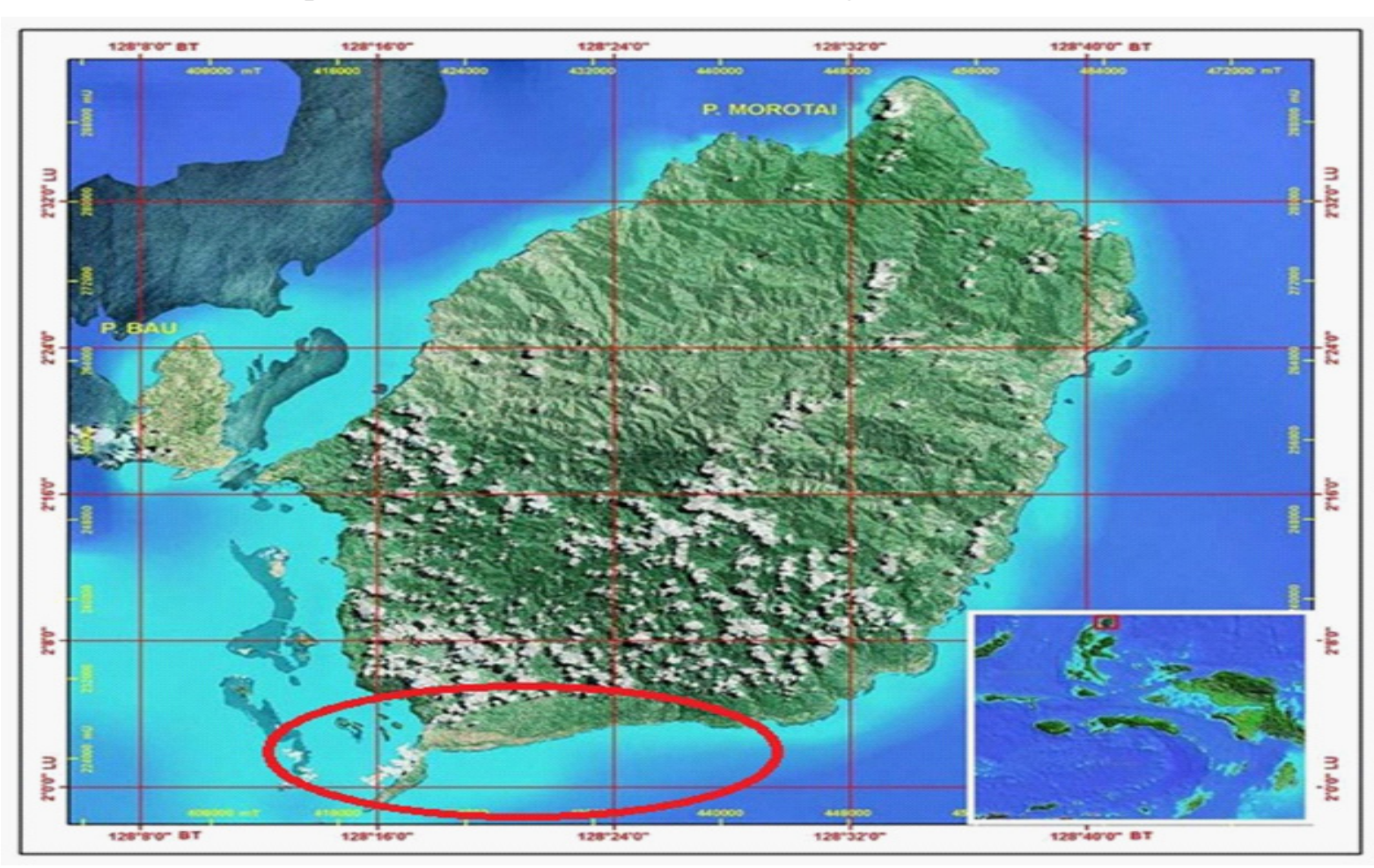

Peta Lokasi Penelitian

(Sumber Peta: http://www/lapanrs.com/gis/peta/429) berpenduduk 53.000-an jiwa (27.000an laki-laki dan 26.000-an perempuan), dengan tingkat kepadatan sebesar 107 jiwa per km² (Badan Pusat Statistik, 2010).

Kondisi Morotai saat ini, jauh berbeda dengan kondisi Morotai pada saat pulau in menjadi pangkalan militer sekutu. Berbaga fasilitas yang dulunya dibangun oleh pasukan sekutu, kini tinggal puing-puing saja, kecuali beberapa fasilitas yang masih difungsikan seperti bandar udara Pitu (Pitu Strip). Bahkan bangkai pesawat dan kapal-kapal perang yang dulunya masih ada di Morotai kini tidak ada lagi karena maraknya kasus pencurian besi tua. Selain itu, masyarakat setempat juga menjadikan bangkai-bangkai pesawat sebagai kerajinan yang dikenal dengan kerajinan besi putih. Sisa-sisa peninggalan Perang Dunia I di Morotai yang masih dapat diidentifikas saat ini merupakan koleksi penduduk yang dijadikan sebagai koleksi sebuah museum mini tentang sejarah Perang Dunia II di Morotai

Pembahasan tentang tinggalan rkeologi di Morotai, akan diuraikan dalam dua 
pembahasan yaitu; deskripsi tentang toponimtoponim Perang Dunia II, serta deskripsi tentang artefak lepas yang merupakan koleksi yang dimiliki oleh penduduk setempat. a. Toponim

Toponim-toponim yang dimaksudkan dalam pembahasan ini adalah lokasi-lokasi yang dulunya dimanfaatkan oleh pasukan sekutu untuk membangun berbagai sarana dan prasarana pangkalan militer. Beberapa lokas tersebut, diantaranya: landasan pesawat (Pit Strip), lokasi pendaratan sekutu, Army Dock, Gua Aer Kaca.

Selain Gua Aer Kaca, di lokasi lain juga ditemukan beberapa gua-gua alam yang dijadikan sebagai sumber air. Menurut informasi masyarakat, lokasi-lokasi ini jug merupakan tempat pemandian bagi tentara sekutu. Sulitnya sumber air di pulau Morotai menyebabkan sekutu memanfaatkan kondisi alam untuk memperoleh air.

Selain toponim-toponim tersebut, beberapa lokasi yang memiliki keterkaitan dengan Perang Dunia II di Morotai diantaranya adalah Pulau Zum-Zum yang disebut sebagai markas besar Jenderal Mc. Arthur dan dijadikan sebagai pusat komando serangan sekutu ke Philipina.

b. Data Artefaktual

Artefak lepas yang akan diuraikan pada bagian ini dibagi atas tiga pembahasan yaitu artefak lepas yang merupakan koleks museum mini, koleksi milik Bapak Haris, da koleksi milik Bapak Muklis Aramin.

- Koleksi Museum Min

Museum mini berada di Kota Daruba, dan merupakan museum yang diprakarsa oleh Bapak Muklis Eso. Museum ini didirikan atas dedikasi dan kesadaran Muklis Eso dan kawan-kawan untuk melestarikan sisa Perang Dunia II yang ada di Morotai. Koleksi yang berada di museum ini, terdiri atas: berbaga jenis senjata, peluru, seragam, asesoris, botol, peralatan listrik, peralatan makan/minum, dan lain-lain

- Koleksi Milik Bapak Haris

Koleksi bapak Haris terdiri ata proyektil berbagai ukuran; pening; sendok; botol dengan ukuran DM 2,5 cm, DD = 9 $\mathrm{cm} \mathrm{P}=29 \mathrm{~cm}$ terdapat tulisan "this Bottle is the property of BROOKES LEMOS Limited and cannot of be Legally USED OTHERS FOR ANY PURPOSE, pada sisi lain terdapat juga tulisan "BROOKE'S LEMOS LIMITED MANUFACTURERS OF "LEMOS" REGISTERED TRADE MARK", mur dan baut dari besi, bak besi; dan satu unit mesin fax dengan ukuran $\mathrm{P}=19 \mathrm{~cm}$, dan $\mathrm{L}=$ $13,5 \mathrm{~cm}$ dan terdapat tulisan 7241 .

- Koleksi Bapak Hair Koleksi yang dimiliki oleh Bapak Hair berupa: Tangki Minyak Pesawat dengan ukuran dua tangki yang memiliki ukuran panjang yang sama yaitu $91 \mathrm{~cm}$, sementara ukuran lebar dan tebal yang berbeda yaitu 54 $\mathrm{cm} \times 30 \mathrm{~cm}$ dan $58 \mathrm{~cm} \times 14 \mathrm{~cm}$. Selongsong proyektil sebanyak 38 selongsongdengan masing-masing ukuran $\mathrm{DD}=12,5$ dan $\mathrm{T}=60$ $\mathrm{cm}$, serta $\mathrm{DD}=2 \mathrm{~cm}$ dan $\mathrm{T}=13,5 \mathrm{~cm}$. Dua bagian dari onderdil senjata dengan tipe SMB 2. Serta koleksi lain berupa Bayonet Jepang, kepala rim, dan dua potongan pipa besi yans memiliki panjang $18 \mathrm{~cm}$ dan diameter $2,5 \mathrm{~cm}$ - Koleksi Milik Bapak Muklis Aramin

Tidak banyak koleksi yang dimiliki oleh Bapak Muklis Aramin. Koleksi yang dimiliki saat ini, berupa selongsong besar dengan tipe senjata SMB 12,7 dan selongsong kecil SMB 7,5.

\section{Konsep Tematik Pameran (Storyline)}

Berdasarkan konteks sejarahnya, tinggalan arkeologi yang ada di Pula Morotai merupakan jejak peristiwa yang telah mengubah perjalanan sejarah dunia. Dalam konteks ini, jenis museum yang tepat dalam wacana pen lieux de memori yaitu museum yang didirikan dengan tujuan untuk "menghidupkan" kembali memori-memori yang pernah berlangsung di lokasi ini berkaitan dengan Perang Dunia II. Jenis museum lieux de mémoire, lebih diarahkan pada peran museum sebagai pelestari memori (peristiwa sejara tertentu) dimana museum menjadi tempat penyimpanan pengetahuan tentang masa lampau yang pada gilirannya dapat dijadikan sumber daya memori bagi para pelaku sejarah dari waktu ke waktu (Magetsari, 2009: 11; Mansyur, 2010b: 33).

Dalam konteks museologi, sebuah pameran museum harus disusun berdasarkan tujuan dan maksudnya, pameran sekaligus merupakan wujud penafsiran dengan presentasi yang lengkap, tidak hanya objek tetapi juga konteks, maksud/arti, sejarahsejarah, arti penting dan lain-lain (Edson dan Dean, 1996: 149; Mansyur, 2010a: 52). Oleh
karena itu, dalam fase konseptual ini sebuah pameran museum terlebih dahulu harus memahami konteks benda-benda peninggalan yang nantinya akan dipamerkan.

Selanjutnya, pameran merupakan alat utama yang dapat merepresentasikan museum kepada publik. Melaui pameran-lah, sebuah museum dianggap mampu memberikan beragam pengalaman yang dapat memenuhi kebutuhan manusia akan pengetahuan dan rekreasi. Oleh karena pameran sebagai salah satu wujud produk museum, maka penting untuk menyusun konsep tematik tentang apa yang akan dipamerkan oleh museum. Subpembahasan berikut ini memberi gambaran awal tentang konsep tematik pameran (storyline) museum Perang Dunia II di Morotai

Sebelum pembahasan tentang konsep tematik pameran, terlebih dahulu diuraikan beberapa hal yang menjadi pedoman dasar dalam penyusunan konsep tematik pameran, yaitu: pertama, pemaknaan terhadap bendayaitu: pertama, pemaknaan terhadap bendabenda peninggalan Perang Dunia II tidak hanya terbatas pada kisah pendudukan sekutu tetapi juga harus dimaknai sebagai manisfestasi material dari posisi strategis Pulau Morotai dalam konteks pertahanan dan keamanan NKRI; kedua, Tema pameran tidak hanya terfokus pada informasi macrohistory Perang Dunia II di Morotai, tetapi juga memberi informasi tentang apa yang dialami oleh para pelaku sejarah. Demikian halnya, bahwa informasi berdasarkan kesaksian pelaku sejarah tidak hanya berdasarkan pada kedua pihak yaitu Jepang maupun sekutu, tetapi yang lebih penting adalah apa yang dialami oleh masyarakat Morotai pada saa itu. Dengan konsep penyajian pameran seperti ini, diharapkan masyarakat memiliki ikatan emosional dengan museum; ketiga, aspek lain yang juga penting adalah tema khusus tentang kondisi benda-benda peninggalan Perang Dunia II yang ada di Morotai. Sebagaiman diketahui bahwa bukti-bukti peninggalan Perang Dunia II saat ini mulai kurang, bahkan terancam habis karena berbagai aktivitas masyarakat. Oleh karena itu, tema khusus yang dapat menggambarkan penyebab berkurangnya bukti-bukti peninggalan Perang Dunia II harus ditampilkan. Ha ini dimaksudkan sebagai bagian untuk menumbuhkan kesadaran masyarakat akan pentingnya sumberdaya arkeologi di Morotai.

Berdasarkan ketiga poin penting yang mendasari penyusunan konsep tematik penyajian pameran sebagaimana disebutkan atas, maka unsur tema yang dapat ditampilkan oleh Museum Perang Dunia II di Morotai, adalah; Periode Perang Dunia II di Morotai, Kesaksian Pelaku Sejarah, Kisah Nakamura dan Nasib Peninggalan Perang Dunia II di Morotai.

a. Tema Pertama: Periode Perang Dunia II di Morotai

Unsur tema pertama ini merupakan bagian yang akan mengungkap aspek macrohistory Perang Dunia II. Tema ini selanjutnya akan dibagi atas beberapa sub tema, yaitu informasi awal tentang penyebab terjadinya Perang Dunia II, peran dan posisi strategis Pulau Morotai dalam konteks geo-strategi Perang Dunia II baik oleh pihak Jepang maupun pihak sekutu. Sub tema berikutnya adalah berbagai informasi tentang periode pendudukan Jepang di Morotai, serta sub tema entang periode pendaratan pasukan sekutu di Morotai.

b. Tema Kedua: Kesaksian Pelaku Sejarah Unsur tema kedua adalah bagian yan akan memberi informasi tentang berbaga kesaksian para pelaku sejarah baik dari pihak Jepang maupun pihak sekutu. Kesaksian pelaku sejarah sekaligus menampilkan kesaksian masyarakat Morotai yang menjadi 
pelaku sejarah pada masa itu. Unsur tema ini dimaksudkan untuk mengungkap berbagai kisah yang bersifat personal para pelaku sejarah.

Kendala yang mungkin dihadap terkait dengan unsur tema ini adalah sulitny memperoleh informasi para pelaku sejarah yang masih ada hingga sekarang. Oleh karena itu, dibutuhkan keseriusan untuk menelusuri dan menghubungi berbagai pihak yang kemungkinan masih menyimpan berbagai hal terkait dengan kisah Perang Dunia II di Morotai. Bentuk display yang dapat ditampilkan pada unsur tema ini, selain berupa visual maupun audio-visual kesaksian yang mungkin masih dapat diperoleh, juga dapat ditampilkan display berupa klipping koran atau media cetak lain yang memua tentang kesaksian para pelaku sejarah Perang Dunia II di Morotai. Bentuk lain adalah benda-benda pribadi para personil tentara baik pihak Jepang maupun pihak sekutu. Dengan menampilkan benda-benda pribadi sepert ini, maka pengunjung dapat melakukan interpre benda-benda pibadi tersbut. Salah san contohyang dapat ditalka Salah satu con liontin berbentuk hati dengan sebuah tulisa "always", milik seorang tentara sekutu. Tent saja, melihat liontin ini pengunjung akan memiliki interpretasi sendiri tentang pemilik benda tersebut.

\section{c. Tema Ketiga: Kisah Nakamura}

Kisah paling menarik dalam sejarah Perang Dunia II di Morotai adalah kisah tentang perjuangan hidup Nakamura, seorang tentara Jepang yang berhasil melarika diri dan bersembunyi di hutan pada saa berlangsungnya pendudukan pasukan sekutu. Bernama lengkap Teruo Nakamura lahir pad tahun 1919 di Taiwan, mengikuti wajib militer tahun 1943 dan menjadi personil Angkatan Darat Kekaisaran Jepang unit Sukarela Takasago ke-4. Pada saat pasukan Jepang terdesak oleh serangan pasukan sekutu, Nakamura bersama pasukan Jepang lainnya bersembunyi di hutan Morotai dan teguh tidak menyerah kepada pasukan sekutu. Ia dinyatakan tewas pada Maret 1945, setelah beberapa kali operasi pembersihan sisa-sis pasukan Jepang yang dilakukan oleh pasukan sekutu selama bulan Oktober 1944 hingga sekutu selama bulan Oktober 1944 hingga sekutu dari Morotai, beberapa pasukan Jepang kemudian ditemukan dan di-repatriasi ke Jepang pada dekade 1950-an. Nakamura akhirnya tinggal sendiri dan berhasil bertaha kamp kecil yang terdiri atas pondok kecil dan ladang seluas 20-30 meter.

Setelah 30-an tahun bertahan di hutan Morotai, Nakamura kemudian ditemukan pad tahun 1974 setelah adanya laporan penduduk Morotai tentang keberadaan seseorang yang misterius di tengah hutan Morotai. Kedutaan Jepang kemudian melakukan kerjasama dengan pasukan TNI-AU untuk melakukan misi pencarian, Nakamura ditemukan pada 18 Desember 1974. Ia kemudian diterbangkan ke Jakarta dan dirawat beberapa saat $d$ Rumah Sakit Pelni di Jakarta, setelahnya ia kemudian memutuskan untuk direpatriasi langsung ke Taiwan dan meninggal pada tahun 1979 karena kanker paru-paru di negara kelahirannya.

Kisah Nakamura tidak hanya berhenti setelah ia ditemukan di Morotai pada tahun 1974. Kisahnya masih berlanjut pada proses repatriasi serta konpensasi yang layak ia terima setelah menjadi bagian dari tentara Jepang serta keteguhannya untuk tidak menyerah kepada musuh. Sebagai tentara Jepang yang tidak memiliki kewarganegaraan Jepang dan melalui jalur wajib militer dan hanya berstatus sebagai prajurit, Nakamura tidak berhak mendapat tunjangan yang lebih karen status tersebut. Kondisi inilah, yang mungkin menjadi pertimbangan Nakamura sehingga memutuskan kembali ke negara kelahirannya Hal inipun menyebabkan kontroversi di Jepang karena adanya perlakuan berbeda antara pasukan yang berasal dari Jepang dengan pasukan yang direkrut dari negara koloni termasuk Taiwan.

Dalam konteks pemaknaan museum, banyak pelajaran yang dapat dipetik dari kisah Nakamura. Penyajian tentang tema khusus kisah Nakamura dapat dimulai dengan profil Nakamura, serta perjalanan hidupnya menjadi bagian dari tentara Jepang yang kemudian ditempatkan di Morotai. Selanjutnya, informasi tentang bagaimana Nakamura memulai petualangannya bertahan di hutan Morotai setelah pendaratan pasukan sekutu. Penyajian ini merupakan sebuah rekonstruksi tentang kemampuan Nakamura bertahan selama 30 tahun di tempat persembunyian hingga kisah penemuannya pada tahun 1974. Penyajian selanjutnya adalah proses repatriasi serta kontroversi yang terjadi di Jepang setelah penemuan Nakamura.

Sementara itu, bentuk display yang dapat ditampilkan adalah display teks, dan jika memungkinkan adalah benda benda milik Nakamura k Selain itu, sebuah film dokumenter tentang Selain itu, sebuah film dokumenter tentang
kisah Nakamura adalah sebuah tayangan yang menarik bagi pengunjung museum.

d. Tema Keempat: Peninggalan Perang Dunia II di Morotai

Tema keempat adalah penyajian yang mampu merangkum informasi tentang apa saja yang menyebabkan berkurangnya sisa Perang Dunia II, serta hilangnya beberapa bukti yang berkaitan dengan Perang Dunia II di Morotai. Sebagaimana diketahui, sejak pendudukan militer Jepang hingga pendaratan pendudukan militer Jepang hingai peralatan dan fasilitas perang baik dalam jumlah maupun ukuran memiliki skala besar. Namun, apa yang ada saat init tentang keberadaan berbagai peralatan dan fasilitas perang yang ada pada saat itu. Tentu saja kondisi ini menimbulkan pertanyaan mengapa hal ini terjadi. Melalui tema keempat ini, museum berupaya memberikan informasi untuk menjelaskan berbagai penyebab yang ada. Oleh karena itu, alur penyajian dimulai dengan pengantar yang menpu ment dengan pengantr yang mamemberi gambaran tentang apa saja yang ada dan fasilitas yang dibangun oleh kedua pihak baik militer Jepang maupun pasukan Sekutu. Selanjutnya adalah informasi tentang berbagai kegiatan yang menyebabkan hilangnya bukti-bukti Perang Dunia II di Morotai yaitu pengangkutan sisa Perang Dunia II yang dilakukan pada awal kemerdekaan, pencurian sisa-sisa Perang Dunia II sebagai besi tua, serta pembuatan kerajinan besi putih oleh masyarakat setempat.

Bentuk display yang dapat ditampilkan adalah foto-foto yang memuat gambar situasi pada masa perang serta pembangunan berbagai fasilitas yang dilakukan oleh Jepang dan sekutu. Penyajian juga dapat menampilkan kesaksian masyarakat terkait dengan kegiatan pencurian besi tua maupun pembuatan kerajinan besi putih melalu bentuk audio dan audio-visual. Bentuk lain, jika memungkinkan adalah statistik yang menggambarkan tentang volume kegiatan pencurian besi tua maupun pembuatan kerajinan besi putih.

\section{PENUTUP}

Morotai dalam konteks kewilayahan memiliki peran penting dalam sejarah masa lalu. Peran penting ini tampak pada posis geografis Morotai sebagai pulau terdepan yang berbatasan langsung dengan wilayah Pasifik. Dalam konteks Perang Dunia II, posisi geografis Morotai merupakan bagian dari gugusan kontinental kepulauan antar negara yang membentang dari wilayah utar (Jepang) ke wilayah selatan (Australia) Posisi strategis inilah yang membuat kawasan ini menjadi ajang pertempuran dua kekuatan militer terbesar pada masa Perang Dunia II. Keberhasilan sekutu merebut Morota yang berbatasan dengan Philipina dan menjadikannya sebagai pangkalan milite merupakan titik balik keberhasilan Sekutu mengalahkan militer Jepang dalam kancah Perang Dunia II. Dalam konteks inilah, peran Morotai pada masa Perang Dunia II menjadi penting ditilik dari kepentingan militer Sekutu.

Saat ini, terdapat banyak peninggalan Perang Dunia II di Morotai yang menjadi koleksi masyarakat setempat. Kesadaran masyarakat untuk menyimpan dan merawat koleksi peninggalan Perang Dunia II tersebut diwujudkan dengan mendirikan sebuah museum mini. Hal ini tentu merupakan 
potensi awal pendirian sebuah museum yang dapat memberikan informasi terkait periode Perang Dunia II di Morotai.

Di sisi lain, dalam rangka Sail Morotai yang telah dilaksanakan pada tahun 2012, pemerintah pusat berkeinginan untuk mendirikan sebuah museum di Morotai. Dalam konteks wacana pendirian museum inilah, diharapkan tidak hanya terbatas pada pendirian museum yang sekedar mendisplay atau memamerkan benda-benda tanpa bobot informasi. Dengan demikian, studi awal konsep tematik museum Perang Dunia II sebagaimana yang telah dibahas sebelumnya dapat memberikan alur cerita atau storyline, sehingga mampu memberikan bobot informasi tinggalan arkeologi yang masih ada di Morotai.

Demikian, dalam kaitan dengan wacana pemerintah tentang pendirian museum Perang Dunia II di Morotai yang bertepatan dengan penyelenggaraan Sail Morotai, tulisan ini diharapkan memberi sumbangan pemikiran terkait dengan konsep tematik museum ini nantinya.

$* * * * *$

\section{DAFTAR PUSTAKA}

Badan Pusat Statistik. 2010. Hasil Sensus Penduduk 2010, Pulau Morotai, Data Agregat Per Kecamatan. www.sp2010. bps.go.id., diakses tanggal 10 Mei 2012, dari:

http://www.sp2010.bps.go.id/files/ ebook/8207.pdf

Dean, David. 2002. Museum Exhibition: Theory and Practice. London: Roudledge.

Deputi Bidang Penginderaan Jauh Lembaga Penerbangan dan Antariksa Nasional. 2012. Wilayah: Pulau Morotai, Peta: Peta Citra Satelit Tiga Dimensi. www. lapanrs.com., diakses tanggah 15 Mei 2012, dari

http://www.lapanrs.com/gis/peta/429

Edson, G. dan D. Dean. 1996. The Handbookfor Museums. London. Roudlege.

Historynet, 2011. World War II: Capture of Morotai. www.historynet.com., diakses tanggal 10 November 2011, dari:

http://www.historynet.com/world-warii-capture-of-morotai.htm

Magetsari, Noerhadi. 2009. "Pemaknaan Museum untuk Masa Kini”. Makalah disampaikan dalam "Diskusi dan Komunikasi Museum", di Jambi tanggal 4-7 Mei 2009. Tidak Terbit.

Mansyur, Syahruddin., 2010a. "Konstruksi Baru Pameran Museum Kota Makassar". Tesis. Fakultas Ilmu Pengetahuan Budaya: Jakarta: Universitas Indonesia. Tidak Terbit.

Mansyur, Syahruddin., 2010b. "Museum Negeri: Sebuah Upaya Melestarikan Memori Kolektif". dalam KapataVol. 6 No. 11, November 2010 ISSN 1858-4101:25-48. Ambon: Balai Arkeologi Ambon.

Mansyur, Syahruddin., 2011. “Tinggalan Perang Dunia II di Ambon: Tinjauan atas Sarana Pertahanan dan Konteks Sejarahnya”. dalam Kapata Vol. 7 No. 12, Juli 2011 ISSN 1858-4101: 43-61. Ambon: Balai Arkeologi Ambon.

Marsono. 2005. Sejarah Pemerintahan dalam Negeri. Jakarta: CV Eka Jaya.

Moleong, Lexi, J., 2008. Metodologi Penelitian Kualitatif (edisi revisi). Bandung: PT Remaja Rosdakarya, 2008.

Ojong., P.K., 2006. Perang Pasifik, Cetakan IX 2006. Jakarta: Penerbit Buku Kompas

Smith, R.R., 2011. The War in The Pacific: The Approach to The Philippines. http:// www.ibiblio.org/., diakses tanggal 10 November 2012.

Tim Penelitian. 2011. Laporan Penelitian Arkeologi Terapan: Studi Konseptual Museum Perang Dunia II di Pulau Morotai. Ambon: Balai Arkeologi Ambon.

Wikipedia. 2011. Perang Dunia II. www. wikipedia., diakses tanggal 18 Februari 2011, dari: http://id.wikipedia.org/wiki/Perang_ dunia_ii

Wikipedia. 2011. Battle of Morotai. www. wikipedia., diakses tanggal 10 November 2011, dari: en.wikipedia.org/wiki/Battle_of_ Morotai 